International Journal of Social Science and Economic Research

ISSN: 2455-8834

Volume:05, Issue:07 "July 2020"

\title{
MUSIC AND ARCHIVAL: ASSESSING THE CULTURAL CONSERVATION OF MUSIC IN INDIA BY PUBLIC INSTITUTIONS
}

\author{
Namay Agarwal
}

Step by Step School Noida

DOI: 10.46609/IJSSER.2020.v05i07.030 URL: https://doi.org/10.46609/IJSSER.2020.v05i07.030

\begin{abstract}
Ethnomusicology is the study of music from cultural and social perspectives. This paper has determined that there is a coherent link between culture and music and that studying the music of different communities gives us valuable insights about their culture and engagement with other communities. Tracing these links between cultures and communities has been established as a useful means of promoting socio-cultural harmony both within and beyond national boundaries, which makes ethnomusicological research important in today's hostile and populist geopolitical environment. This paper has also explored the efforts made by the Indian government to facilitate the culturala conservation of music and conduct research surrounding it. Whilst efforts made by India surpass those made by other developing countries, it has been found that academia in this sphere has been dominated by 'upper caste' narratives at the cost of subaltern ones. The solution to this lies in expanding accessibility and scope of research of these institutions and centers with an aim of making research reflective of indigenous and subaltern cultures.
\end{abstract}

Keywords: Ethnomusicology, music, communities ,cultural, government.

\section{Introduction}

Culture is defined as the ideas, customs, and social behaviors specific to a set of people or a community. It is the manifestation of collective human intellectual achievement and is reflected in art, language, and social behavior. Culture gives individuals a common ground and enables them to operate reasonably in a shared environment (Bloch, 1998). Culture, this is a form of knowledge which depends on the operation of memory, and hence must be acquired, stored, and recovered (Widdess, 2012). It is one of the most prevalent and visible identity markers that unites or divides people and affects their economic, social, and political decisions. Cultural knowledge is usually acquired non-verbally, through repeated observation and imitation of 


\section{International Journal of Social Science and Economic Research}

ISSN: $2455-8834$

Volume:05, Issue:07 "July 2020"

behavior that is considered routine. It is implicitly emulated by members of a society without any active explicit intervention. Through the course of history, culture has solidified itself into nonlinguistic instruments and media. Even though music is often referential and effective, and is used as a medium of communicating messages, it also functions as the articulation of the state of mind shared by a community of people, that is developed through the course of time. Most importantly, music has been one of the most popular ways of expressing lived experiences, commonalities in which strengthen cultural identity (Barton, 2018).

Cultural factors interact with the structural and stylistic features of music in a complex way that defines it and gives it specific meanings, which are often multi-layered and fluctuating. Such meanings can be specifically identified by studying musical components such as lyrics, composition and accompanying bodily movements, ritual actions, and visual symbols. Even though the implication of far structural features of music on cultural meaning has not yet been clearly established, research surrounding Bulgarian folk music reveals musical performance practices to be deeply permeated with political and social meanings (Rice, 1994). Research conducted inside and outside the ethnomusicological discipline has determined that music contributes significantly to perceptions of national identity. It is argued that the fluidity of music allows for the cultural amalgamation of diverse identities by establishing a common ground (Wade, 2000). The government of India too followed this approach in 1988, by ordering the development of the 'Mile Sur' (meeting of musical notes) campaign. Musicians from diverse ethnic, regional, and linguistic backgrounds were brought together by the Doordarshan- the state broadcasting agency in an attempt to promote national integration and unity in diversity (Goyal, 2017).

Ethnomusicology is defined as the anthropology or ethnography of music and includes the study of all kinds of music from across the world from an anthropological, intercultural, and sociological perspective (Seeger, 1983). The underlying structures of culture, which represent generations of human intellectual development and struggle can barely be understood through the limits of linguistics but necessitates thorough observation that ethnomusicology provides for. Learning to play complex musical instruments, through observation and imitation allows ethnomusicologists to access the context and meanings that musical sounds represent for members of a particular community (Widdess, 2012). These representations can be located in relation to culture-specific concepts, functions, social and political dynamics of music through the course of history, and human experiences around it. The most common and basic characterization of music is that it is 'humanly organized sound'. (Blacking, 1973). This distinguishes music from unintentional or random sounds and establishes it as a process that is purposefully engaged in by the members of a particular society in ways that align with dominant or accepted socio-cultural norms. The study of the organized process of making music in society 


\section{International Journal of Social Science and Economic Research}

ISSN: $2455-8834$

Volume:05, Issue:07 "July 2020"

allows us to determine levels of acceptability, and trace underlying behaviors of music creators and consumers.

There are two approaches to ethnomusicology- anthropological and musicological. The former seeks to study music to learn about people and culture whereas the latter study people and cultures to learn about music. There exists a link between music, culture, and identity, and ethnomusicology helps us understand the psychological and social processes that guide human behavior in different contexts. Music is linked with nationalism, resistance, and social hierarchies- all of which find representation in a community's music (Turino, 2000). At a point in time where documented history is hegemonized by former colonists, and privileged classes, music has become one of the most important ways of promoting subaltern narratives and struggles. It thus becomes very important for governments, especially those of former colonies to promote research and exploration into ethnomusicology to preserve and promote cultural identity and values based on which their nation is built.

\section{Background}

Ethnomusicology is described as a holistic investigation of music within its cultural contexts. It is an interdisciplinary field of exploration which includes the study of folklore, psychology, cultural anthropology, linguistics, comparative musicology, music theory, and history (See Hood, 1969). It traces its origin to comparative musicology and initially sought to compare Western music (which was considered to be the established standard) with other forms of music, in an attempt to understand the cultural context of the 'others (Pegg, 2001). Even though the field is not strictly defined, it seeks to explore music from beyond a purely sonic and historical perspective, and instead examines it within culture, as culture, and as a reflection of culture (Nettl, 2005). Ethnomusicology has grown to emerge as a field that brings together professionals from the fields of psychology, anthropology, sociology, and musicology to not only study the relationship between culture and music through history but also to apply that knowledge in fields of public policy and mental healthcare (through music therapy) (Merriam, 1975).

Folklore studies, which focuses on the preservation and continuation of traditional folk music, is also considered to be the precursor to ethnomusicology. Folklore studies were motivated by nationalism and the search for nationalistic identity, which are clearly visible in the music produced in Eastern Europe in the 19th century by the likes of Edvard Grieg and Jean Sibelius (Myers, 1992). Even though music has always been used to channelize nationalistic or tribalistic sentiments, an academic inquiry into this phenomenon was launched by the folklorists in the preWorld War 2 era. Along with preservation and revival of music for nationalistic purposes, this period also witnessed groundbreaking cross-cultural research, which manifested in the study differences in music and culture between the American States (depending on the heritage of the 


\section{International Journal of Social Science and Economic Research}

ISSN: $2455-8834$

Volume:05, Issue:07 "July 2020"

settlers of these regions), and the study of Negro Spirituals and the intermingling of European and African music due to colonization and the Atlantic Slave Trade (Pegg, et. al., 2001). Even though some narratives of this research were infested with racism and bias, they established the manifestation of cultural heritage in music. This period also marked the emergence of Comparative Musicology, which seeks to classify music from cultures across the world to demonstrate their geographic distribution, examine trends, and understand the causations behind the creation and evolution of music in different communities (Seel, 2011). Ethical problems in ethnomusicology started to emerge after the second world war. These were centered around problems pertaining to eurocentrism, and the establishment of European or western music as a standard for comparison and study (Merriam, 1975).

Ethnomusicological research and exploration developed a more global outlook in the 1950s, as scholars focused their fieldwork and analysis to study subaltern cultures and music, especially on the representation of colonialism and struggles against the same (Merriam, 1975). By the 21st century, there was greater consideration for awareness around the diversity of sociological contexts, and the impact of globalization on the same. Whilst globalization has had an undeniable effect on cultural homogeneity, it has also contributed to the intermingling of cultures and the broadening of means and forms of musical expression. Postcolonial thought has become even more important, and attempts have been made by scholars of subaltern communities to deconstruct European hegemony over the study of global music (Agawu, 2003). For example, studies now focus on tracing differences and similarities between different types of African music, without European music being used as a standard for comparison which enables us to reconstruct and understand the complexities of varied African music types that previously went unexplored.

\section{Discussion}

Music has also served as an important medium for oral tradition and history. It has been used by religions, kingdoms, and individuals to propagate their culture and histories. Folk songs collected in oral tradition have often been traced to literary sources. In Medieval Europe, the catholic church targeted folk music because of its association with paganism (Nettl, 2005). However, both European Folk Music and Christian Liturgical verses have assimilated with each other which is a testimony of the fact that engagement between different cultures and communities is visible in the ways their music styles engage with each other. Folk music was also incorporated into music produced during the Renaissance. The popularity of humanistic values and principles made this more acceptable for the literate Christian urban middle class. Similar trends are also noticeable during the Protestant Reformation. Music compositions did not always have a religious sentiment but were instead a reflection of all aspects of society. These traditions and customs have been carried forward, partly due to their influence on the music and compositions 


\section{International Journal of Social Science and Economic Research}

ISSN: $2455-8834$

Volume:05, Issue:07 "July 2020"

which continue to be popular to date. Sufi music portrays history by incorporating events ranging from the dispute over succession to Prophet Muhammad's caliphate and the subsequent creation of the Shia-Sunni divide to the lives of Sufi saints in its lyrics (Akhtar, 2017)

Tracing historic engagements between different cultures and influences on each other is advantageous for social and public narratives in the contemporary world. Urdu is an Indo-Aryan language spoken in the Indian Subcontinent which was created by the amalgamation and interaction of Hindu and Muslim cultures in the region. Even though it is mutually intelligible with Hindi, it also uses Persian vocabulary and grammar structures. Qawwali is a form of Islamic devotional signings that significantly relies on Urdu and other languages like Hindi, Bengali, and Punjabi which are native to India (Hussain 2012). India and Pakistan, now separate countries with Hindu and Muslim majority populations respectively, have had territorial disputes since their independence and have attempted to otherize each others' populations and cultures in an attempt to justify aggression. More recently, this has manifested in the successive elections of right-wing governments and an increase in violence against religious minorities. Qawwali music continues to be popular in India and has even made its way to the heights of Bollywood. Studying and raising awareness about historic cultural links between followers of religions who are hostile towards each other can contribute to the reduction of mutual agreement between them (Masaeli \& Prabhakar, 2018).

Similar to most developing countries, ethnomusicological research in India continues to be nascent (Jairazbhoy, 2019). It is important to explore this field extensively to trace engagements and connections between the diverse cultures of India. The government has established public institutions to study the links between culture and music. Sangeet Natak Akedemi is a national level academy for performing arts that were established by the government of India in 1952. It serves as the apex body of performing arts in the country and works to preserve and promote the diverse cultural heritage of India which is expressed in dance, music, and drama. It has the largest archive of audio-visual tapes, photographs, and films that is extensively used for researching performing arts from anthropological, socio-historical, and ethnomusical perspectives. It focuses on collecting and recording works of cultural significance, which are available for academic research. The academy also works with state and regional level organizations, provides grants to aid research, documentation, and publishing in the performing arts, and organises and subsidises academic seminars and conferences. Most importantly, it works to strengthen and foster cultural contacts between different cultures and regions of India, and between India and the rest of the world. The Indira Gandhi National Center for the arts is a public institution that focuses on the experience and the interdisciplinary study of the arts, including music. It focuses on the integration of art with the larger matrix of human culture. It operates regional centers all across the country- each which focuses on indigenous cultures of 


\section{International Journal of Social Science and Economic Research}

ISSN: $2455-8834$

Volume:05, Issue:07 "July 2020"

that particular area. Other public institutions that research the field of ethnomusicology include the Center for Cultural Resources and Training, and regional cultural centers that are spread all across the country (Jairazbhoy, 2019). The past few years have witnessed private investment for ethnomusicological research from organizations including the American Institute for Indian Studies (which runs the Archives and Research Centre for Ethnomusicology), and the Tata Trusts.

\section{Conclusion}

The documentation of music as a representation of cultural heritage and history facilitates a comprehensive understanding of society. This is important because the decisions that we make as a society today depend greatly on how we view ourselves and our histories. There has been a rise in right-wing populist politics across the world, including in India. Narratives within that have attempted to separate Hindu and Muslim cultures and civilizations. These narratives are not new and had been used to justify the partition of India in 1947, a move which destabilized the subcontinent and took millions of innocent lives. Despite classes between Hindu and Muslim rulers centuries ago, people of these religions have lived in harmony for generations, which has impacted both cultures severely and is reflected in respective music styles. There is a need to study these interactions and integrations to increase awareness about cultural exchanges which can in turn reduce religious hostilities in this area. India also has a diverse population with varying cultural practices. Subaltern narratives in India, including cultures of Adivasis, Dalits and other oppressed minority groups often fail to be accommodated in the mainstream definition of culture through education and media. Studying their cultures by studying their music can be a useful method to promote the histories and struggles of these communities, which is often the first step in formulating (or in this case continuing and expanding) emancipatory policies and affirmative action.

The efforts of the Indian government aimed at promoting ethnomusicological research have been substantial when compared to other developing countries. However, there is a need to expand the scope of this exploration. Critics claim that the lens of research in Indian Academia is privileged, both in terms of caste and class, which prevents oppressed communities from accessing 'exclusionary spaces'. It also promotes Brahmanical narratives at the cost of Tribal and Dalit cultures. Institutes and centers have attempted to enhance access by setting up branches in areas like Ranchi, which have a majority tribal population. Even though these steps are in the right direction, the need for taking more concrete steps to expand the scope and accessibility of ethnomusicological research. Ethnomusicology has provided academia with a unique and holistic lens to view cultures, and engagement between them, both inside and across national boundaries, and it is important for public institutions in India to further facilitate the cultural conservation of music. 


\section{Bibliography}

Agawu, K. (2003). Representing African Music: Postcolonial Notes, Queries, Positions. Routledge. Accessed on 7th July 2020

Akthat, S. Damadam mast Qalandar is a cry of rebellion against established orders. Dawn, 20th February 2017

Barton, G. (2018). The Relationship Between Music, Culture, and Society: Meaning in Music: Implications for Classroom Practice. Music Learning and Teaching in Culturally and Socially Diverse Contexts. Accessed on 4th July 2020

Blacking, J. (1973). How Musical Is Man?. University of Washington Press. Accessed on 6th July 2020

Bloch, M.E.F. (1998). How we think they think: anthropological approaches to cognition, memory, and literacy. Westview Press. Accessed on 3rd July 2020

Goyal, S. (2017). Remembering 'Mile sur mera tumhara', the song of united India. Campaign India. Accessed on 5th July 2020

Hussain, Z. (2012). Is it permissible to listen to Qawwali?. TheSunniWay. Accessed on 8th July 2020

Jairazbhoy, N.A. (2019). Ethnomusicology in the Indian Context. Sahapedia. Accessed on 8th July 2020

Masaeli, M., Prabhakar, M. (2018). India as a Model for Global Development. Scholars Publishing. Accessed on 7th July 2020

Merriam, A.P. (1975). Ethnomusicology Today. Current Musicology. Accessed on 6th July 2020

Myers, H. (1992). Ethnomusicology: An Introduction. Accessed on 7th July 2020

Nettl, B. (2005). The Harmless Drudge: Defining Ethnomusicology. The Study of Ethnomusicology: Thirty-one Issues and Concepts. Accessed on 6th July 2020 
International Journal of Social Science and Economic Research

ISSN: 2455-8834

Volume:05, Issue:07 "July 2020"

Pegg, C. (2001). Ethnomusicology. New Grove Dictionary of Music and Musicians. Accessed on 6th July 2020

Pegg, C., Myers, H., Bohlman P.V., and Stokes, S. (2001). The New Grove Dictionary of Music and Musicians. Macmillan. Accessed on 7th July 2020

Rice, T. (1884). May It Fill Your Soul: Experiencing Bulgarian Music. Accessed on 5th July 2020

Seeger, A. (1983). Why Suyá Sing. Oxford University Press. Accessed on 3rd July 2020

See Hood, M. (1969). Ethnomusicology. Harvard Dictionary of Music - 2nd edition. Accessed on 6th July 2020

Seel, N. M. Comparative Musicology to Ethnomusicology. 2011 Encyclopedia of the Sciences of Learning. Accessed on 8th July 2020

Turino, T. (2000) . Nationalists, Cosmopolitans, and Popular Music in Zimbabwe. University of Chicago Press. Accessed on 3rd July 2020

Wade, P. (2000). Music, Race, and Nation. University of Chicago Press. Accessed on 6th July 2020

Widdess, R. (2012). Music, Meaning, and Culture. Empirical Musicology Review. Accessed on 3rd July 2020 